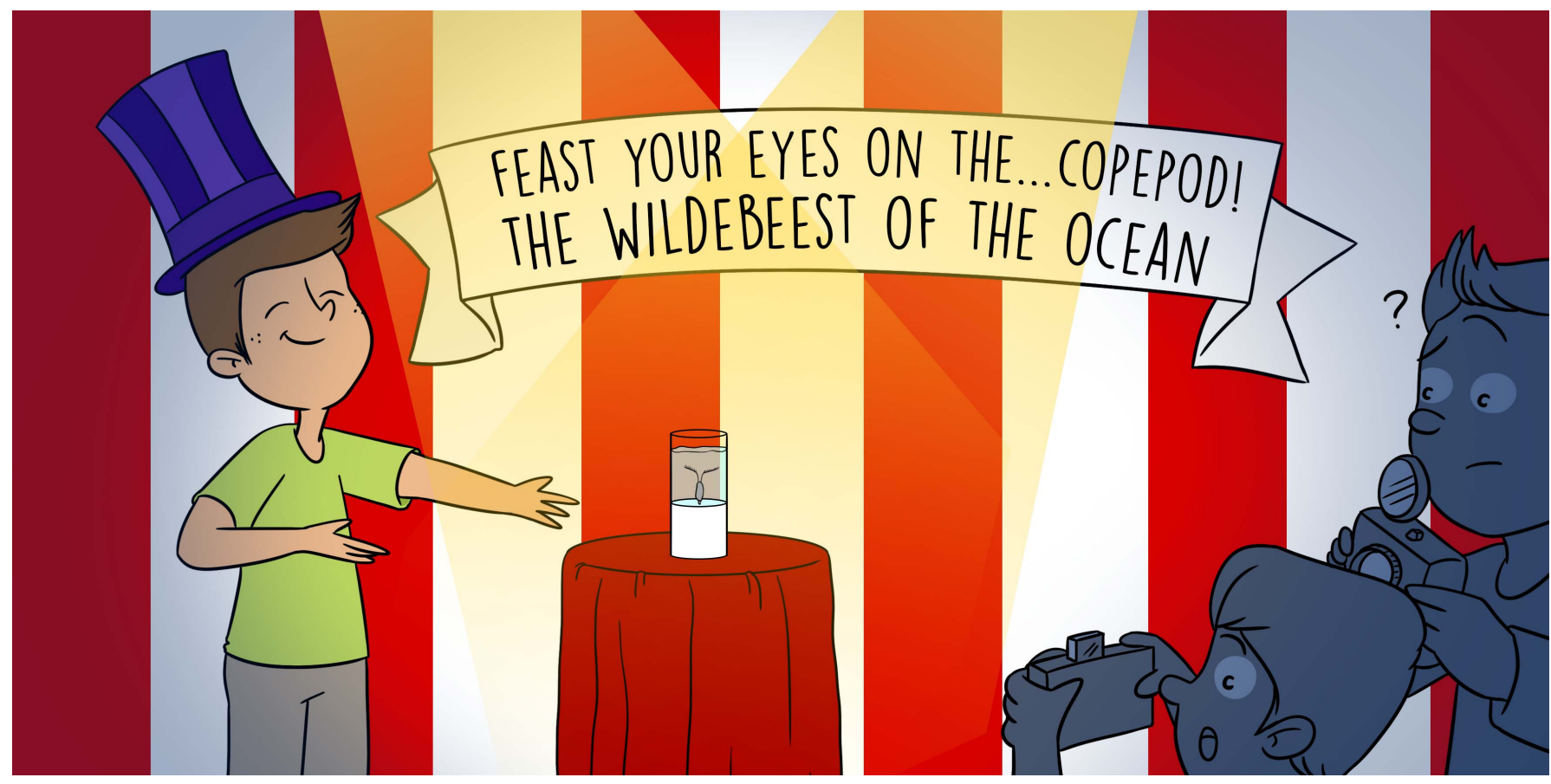

\title{
MARINE COPEPODS, THE WILDEBEEST OF THE OCEAN
}

Daniel J. Mayor ${ }^{1 *}$, Kathryn B. Cook ${ }^{1}$, Thomas R. Anderson ${ }^{2}$, Anna Belcher $^{3}$, Holly Jenkins ${ }^{4}$, Pennie Lindeque ${ }^{5}$, Geraint A. Tarling ${ }^{3}$ and David Pond ${ }^{6}$

${ }^{1}$ Ocean Biogeochemistry \& Ecosystems, National Oceanography Centre, Southampton, United Kingdom

${ }^{2}$ Marine Systems Modelling, National Oceanography Centre, Southampton, United Kingdom

${ }^{3}$ Ecosystems Team, British Antarctic Survey, Cambridge, United Kingdom

${ }^{4}$ School of Ocean and Earth Science, University of Southampton, Southampton, United Kingdom

${ }^{5}$ Plymouth Marine Laboratory, Plymouth, United Kingdom

${ }^{6}$ Institute of Aquaculture, University of Stirling, Stirling, United Kingdom

YOUNG REVIEWER:

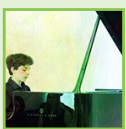

LEONARDO

AGE: 14
Copepods are amongst the most abundant animals on our planet. Who knew?! These small (typically $1-10 \mathrm{~mm}$ ) crustaceans are found in all of the world's oceans and play an important role in regulating Earth's climate. Like wildebeest in the Serengeti graze on grasslands and are food for lions, herbivorous copepods represent a vital link in oceanic food chains between microscopic algae and higher predators, such as fish, birds, and whales. A group of copepods called Calanus are particularly important in the Northern Hemisphere. These tiny-but-mighty animals also share the wildebeest's need to make a large annual migration-but in their case, they sink thousands of meters downwards to spend the winter in the deep, dark ocean. Understanding the lives of marine copepods, and how their 


\section{populations will respond to climate change, is crucial for predicting the future health of the marine environment and how it helps our planet.}

\section{CALANUS THE COPEPOD}

Copepods are tiny crustaceans - distant relatives of crabs and lobsters. They are members of the zooplankton, animals that drift at the mercy of ocean currents. Their name is derived from the Greek words "cope" and "podos," literally "oar-foot," reflecting their large limbs that propel them through the water. At any moment, there are billions of copepods swimming around in all of the world's oceans.

One of the most important groups of copepods in the Northern Hemisphere is called Calanus (Figure 1). A single adult Calanus may only measure a few millimeters in length, but the total existing population of Calanus probably weighs more than all of the 7.7 billion people currently alive on Earth. The huge abundance of Calanus is what makes them so important for the healthy functioning of marine ecosystems.

Just as wildebeest are the main grazers of the Serengeti, so Calanus are the great grazers of the Atlantic and Arctic oceans, feeding on aquatic meadows of phytoplankton, microscopic plant-like algae that bloom in spring. Calanus filter the chlorophyll-rich phytoplankton out of seawater using rapid movements of their feathery mouthparts and their sense of touch (Figure 1).

The bodies of Calanus are transparent, which may explain why the famous eighteenth century Norwegian bishop and scientist Johan Ernst Gunnerus named them after the philosopher Kalanos (Calanus), who refused to wear clothes! For an apparently "simple" animal, Calanus has a complicated life cycle (Figure 2). The cycle begins in spring when adult females release batches of 50 or more eggs into the water. The eggs hatch a day or so later and, being cold-blooded, develop at a rate that is largely controlled by water temperature. Like all crustaceans, Calanus has a rigid external skeleton (exoskeleton) that it must shed in order to grow and develop. In total, there are 12 development stages to their life cycle. During the first 6 they are known as nauplii. These "baby" stages adopt a swimming-by-jumping approach to movement and look like tiny pulsating hands. The 6 later stages are known as copepodites, all of which have the cylindrical shape that is characteristic of Calanus (Figure 1). In the laboratory, it takes between 30 and 80 days for an egg to develop into an adult, depending on the water temperature and feeding conditions. In nature, however, this process is often interrupted by spending winter at great depths as an immature adult (Figure 2). 
Figure 1

$(A, B)$ The marine copepod, Calanus, has broad, sensory antennae and feathery tail-like structures that help them detect and evade predators. (C)

Their green

phytoplankton-packed guts are clearly visible through their

transparent bodies. (D)

Three closely related species of Calanus live together in the Arctic Ocean: Calanus finmarchicus female (left), Calanus glacialis female (middle), and Calanus hyperboreus female (right). (E) The body cavities of

"hibernating" Calanus are packed full of fat to fuel them through the winter months without feeding. Horizontal scale bars represent $\sim 1 \mathrm{~mm}$. All images copyright Daniel Mayor (NOC).
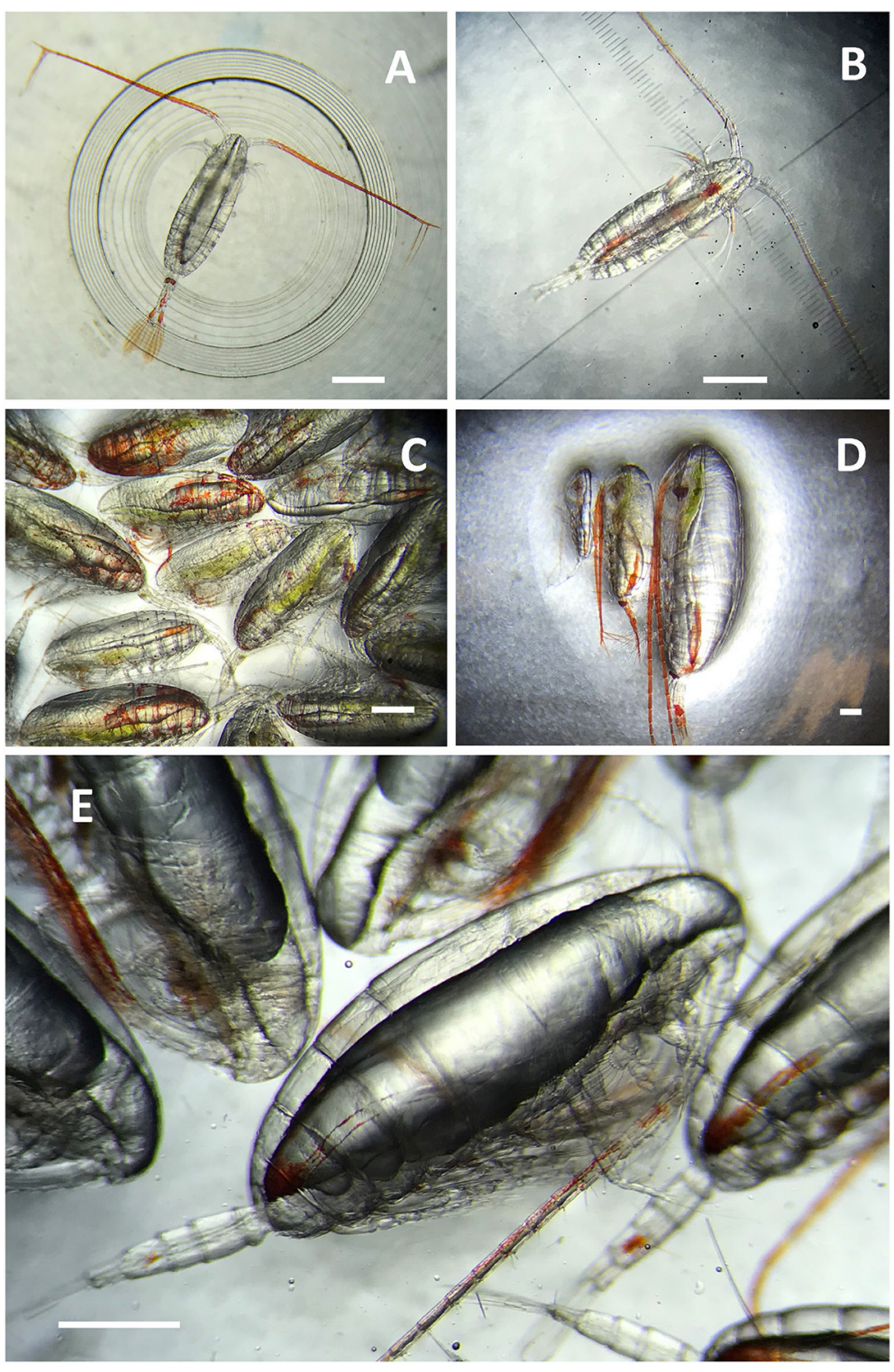

Figure 1

\section{ADAPTATIONS TO LIFE IN THE OPEN OCEAN}

Two of life's main challenges are (1) finding enough food, and (2) avoiding being eaten while doing so. Facing these challenges helps an animal to live long enough to reproduce. Calanus is so successful because of their response to these two challenges.

Calanus congregate to feed on dense patches of phytoplankton near the ocean's surface. Coming together in groups is dangerous-there is nothing to hide behind to avoid being seen by predators - so being transparent helps. But Calanus do not need light to feed, so they reduce their risk of becoming fish food by feeding under the cover of darkness. At sunrise, Calanus descend to hide in the deeper, darker depths. This dilutes their population into the vastness of the deep 
Figure 2

The life cycle of Calanus finmarchicus spend the "active" component of their life in the upper ocean, where they grow through 12

developmental stages ( 6 as nauplii, and 6 as copepodites) of increasing complexity. At the end of summer, immature adult animals (copepodite stage 5) migrate into deep water and enter the dormant component of their life cycle called "diapause." This is similar to hibernation in mammals and other land animals. In early spring, these "sleeping" animals wake up, develop into adults (copepodite stage 6) and migrate back to the surface to reproduce. Image copyright Holly Jenkins (NOC).

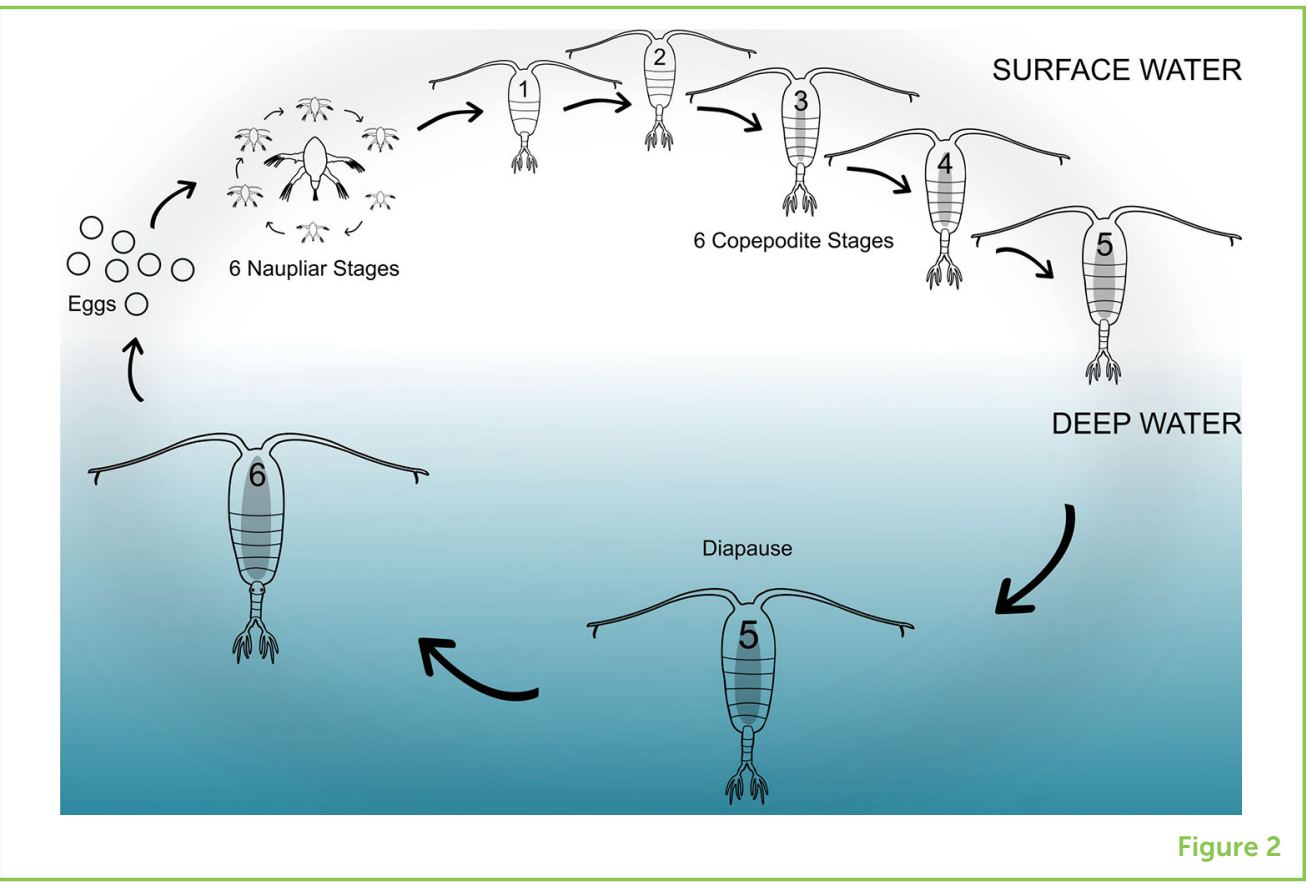

ocean and makes the job of a predator a bit like hunting for a needle in a haystack while also wearing a blindfold. When daylight fades, the migration is reversed and Calanus move back to the surface to feed again.

The dense phytoplankton blooms of spring and early summer provide excellent feeding conditions for Calanus. Just like animals on land, this spring bounty allows Calanus to prepare for the long, dark winter months by storing fat. So much so that their bodies become swollen by their blubbery-burden (Figure 1). As the summer fades to autumn, the phytoplankton that once fuelled Calanus all but disappear and the upper ocean becomes a food desert. This triggers one of the greatest migrations on Earth.

The population of immature Calanus sinks down into the ocean's interior, as deep as $2 \mathrm{~km}$ in some places, where it spends the winter in a dormant state called diapause for up to 9 months (Figure 2). Diapause is similar to hibernation in mammals, such as polar bears, when the animals rely entirely on internal fat reserves. The near-freezing temperature of the deep ocean slows down the rate at which Calanus use up their stored fat reserves, and the perpetual darkness keeps them safe from hungry eyes.

When spring arrives, the dormant population of Calanus awakens and begins its ascent toward the surface. Only now do the animals become adult males and females in anticipation of the next mass feeding and reproductive cycle. Calanus is certainly not the only copepod to overwinter in the deep sea using internal fat stores to survive-but it 
is by far the most abundant one to do so in the North Atlantic and Arctic oceans.

\section{THE IMPORTANCE OF CALANUS}

Spring blooms of phytoplankton transform the North Atlantic and Arctic Oceans into a Calanus-rich soup. Unfortunately for Calanus, their large numbers do not go unnoticed. Countless marine organisms are dependent upon Calanus as a food source. These range from microscopic parasites that live inside their guts, to the bowhead whales that individually consume an estimated 100 tons of Calanus and other crustaceans each year (that is the same as eating 760 wildebeest!). Many species of fish, birds and whales travel huge distances to feed upon the Calanus population explosion that follows the spring phytoplankton bloom.

From a human perspective, the most important relationship is between Calanus and fish. Calanus are the preferred prey of many fish, so when there are a lot of Calanus, there are a lot of fish. And this is good news for the many people who make their livings and feed their families by catching fish, such as cod, herring, capelin, and mackerel.

Calanus also play an important role in helping the oceans regulate the Earth's climate. Phytoplankton grow by transforming carbon dioxide $\left(\mathrm{CO}_{2}\right)$ into living matter via photosynthesis. This process removes hundreds of millions of tons of $\mathrm{CO}_{2}$ from the atmosphere every year. Transformed into phytoplankton, this $\mathrm{CO}_{2}$ becomes Calanus food and, like all animals, some of what gets eaten by Calanus comes out of their rear ends. Calanus produce dense, torpedo-shaped droppings. These droppings transport carbon downwards into the deep ocean, trapping it away from the atmosphere for hundreds or thousands of years. This process helps slow the rate of global warming. During periods of peak Calanus abundance, most of the particles raining down into the ocean's abyss are in the form of these climate change-busting torpedoes. Daily vertical migrations help speed up this process as Calanus drop their "bombs" at depth during daylight hours. These vertical migrations into the deep sea further contribute to removing carbon from the atmosphere. In the ocean depths, Calanus slowly burn off their carbon-rich fat reserves and "breathe out" $\mathrm{CO}_{2}$ into the water. This $\mathrm{CO}_{2}$ would not come back into contact with the atmosphere again for thousands of years.

\section{CLIMATE CHANGE EFFECTS ON CALANUS}

The ever-rising concentration of $\mathrm{CO}_{2}$ in our atmosphere is causing a progressive warming of our climate and thus the ocean. This warming 
is having profound effects on ocean life. Over the last 5 decades, there has been a progressive northward shift in the habitat ranges of Calanus as temperatures there become more favorable to them. Exactly how this redistribution of the Calanus species will affect ocean ecosystems remains unknown.

Ocean warming is also causing a potential mismatch between Calanus and their food. Long-term records show that ocean warming is causing cold-blooded zooplankton, including Calanus, to reach their highest numbers earlier and earlier each year. At first glance this sounds good-the animals develop faster, get fat quicker, and go into diapause sooner (thus avoiding being eaten). The phytoplankton blooms that Calanus depend upon, however, do not show the same response to ocean warming. So, as the years advance, the timing mismatch between Calanus and their food is becoming progressively greater. This has potentially important consequences for the future success of Calanus and the many vital roles they play in the ocean. A major goal of on-going marine research is to understand how Calanus will respond to further climate change, and how these responses will impact the ocean's ability to regulate global climate and produce harvestable resources, such as fish.

\section{DNA FINGERPRINTING CALANUS SPECIES}

There are several related species of Calanus that can be found in huge numbers from the Mediterranean Sea (Calanus helgolandicus), up through the Atlantic Ocean (Calanus helgolandicus, Calanus finmarchicus), and into the Arctic Ocean (Calanus finmarchicus, Calanus glacialis, Calanus hyperboreus) (Figure 1). Being able to identify each species accurately is crucial for us to understand if and how their populations are changing.

The different species of Calanus can be quite difficult to tell apart from each other. Often, the only thing telling one species from another is the subtle difference in the shape of the inside of their legs! Thankfully, modern genetic "fingerprinting" tools can now be used to identify the various species of Calanus. The process of genetically fingerprinting Calanus begins by researchers making many copies of the organism's DNA. This DNA is then cut up into smaller pieces with DNA scissors, called restriction enzymes, which recognize and cut the DNA in very specific places. The sequence of DNA varies between the species, meaning that the DNA is cut in different places for each species. Differences in the resulting DNA strand sizes after cutting can be seen when the pieces are separated using a technique called gel electrophoresis. This technique produces a unique pattern for each species. Just like each item in the supermarket has a unique barcode to identify it at the checkout, we can use the pattern of DNA pieces to identify the species of Calanus (Figure 3). 
Figure 3

Genetic fingerprinting of four Calanus sibling species; Calanus helgolandicus, Calanus finmarchicus, Calanus glacialis, and Calanus hyperboreus. For each species there is a different pattern or "fingerprint". This is because when the DNA is cut up it results in pieces of different sizes. The smaller pieces of DNA run further down the gel than the bigger pieces, resulting in a pattern unique to each species. The pattern is seen as the light bands in each column (four columns for each species), the column labeled $U$ is "undigested," DNA that has not been cut up by the DNA scissors or restriction enzymes. The columns on the outside left and right are DNA markers, bands of DNA of known size that we can use to compare the sizes of our cut-up DNA. For example the undigested DNA is between the 310 and 603 bands of the DNA marker, which indicates the DNA is just over 400 base pairs in size when it has not been cut. Image copyright Pennie Lindeque (PML).

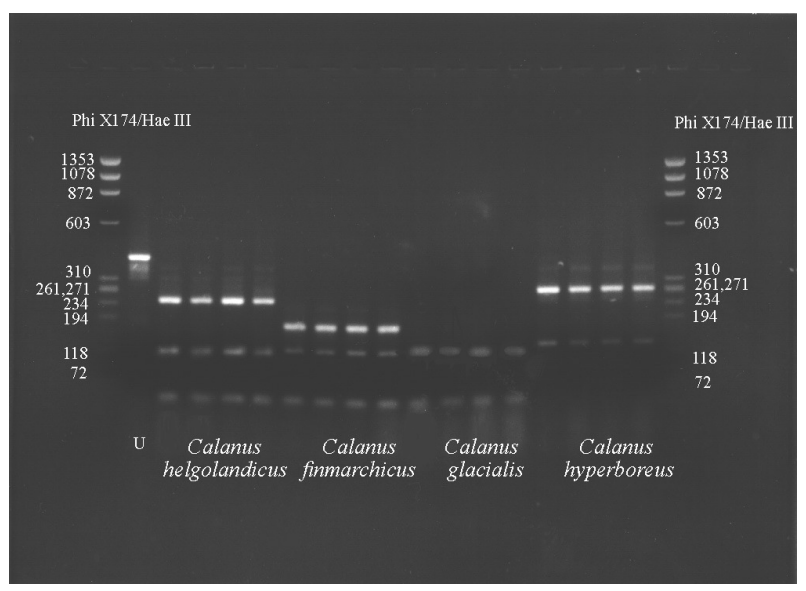

Figure 3

\section{FUTURE OUTLOOK}

Calanus research over the past century has helped us understand and appreciate the importance of these animals for global climate regulation and as a source of food for countless other marine organisms. However, with every new discovery comes the realization that we still have so much to learn. For example, how do these animals decide when to go into and come out of hibernation? And how will future changes in their diet affect their ability to fatten up for winter or produce healthy offspring? Perhaps you will become part of the next generation of plankton biologists that helps answer these and other fundamental questions about Calanus?

SUBMITTED: 22 October 2019; ACCEPTED: 06 February 2020; PUBLISHED ONLINE: 26 February 2020.

\section{EDITED BY: Roxana Suehring, Stockholm University, Sweden}

CITATION: Mayor DJ, Cook KB, Anderson TR, Belcher A, Jenkins H, Lindeque P, Tarling GA and Pond D (2020) Marine Copepods, The Wildebeest of the Ocean. Front. Young Minds 8:18. doi: 10.3389/frym.2020.00018

CONFLICT OF INTEREST: The authors declare that the research was conducted in the absence of any commercial or financial relationships that could be construed as a potential conflict of interest.

COPYRIGHT @ 2020 Mayor, Cook, Anderson, Belcher, Jenkins, Lindeque, Tarling and Pond. This is an open-access article distributed under the terms of the Creative Commons Attribution License (CC BY). The use, distribution or reproduction in other forums is permitted, provided the original author(s) and the copyright owner(s) are credited and that the original publication in this journal is cited, in accordance with accepted academic practice. No use, distribution or reproduction is permitted which does not comply with these terms. 


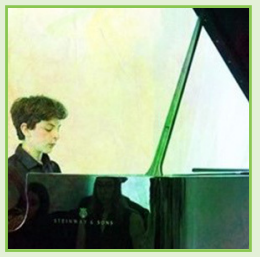

\section{YOUNG REVIEWER}

\section{LEONARDO, AGE: 14}

I am Leonardo, I am in high school now and I really like math and science, I do not really like writing or reading. I hope to become a mathematician. In my free time I mainly play piano and videogames.

\section{AUTHORS}
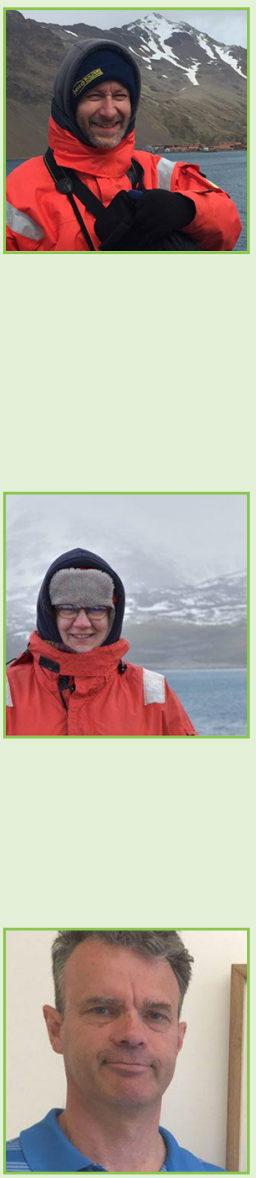

\section{DANIEL J. MAYOR}

I am a Biological Oceanographer, and lead the Pelagic (open-ocean) Ecosystems sub-group at the National Oceanography Centre, UK. My research examines how zooplankton are affected by climate change, and the consequences for the global carbon cycle and climate regulation. Spending time at sea allows me to indulge three of my passions; plankton, traveling, and reggae music (much to the bemusement of my wife and kids)! I really enjoy making things, and am half way through building my own house. See more wonderful plankton on Instagram (oceanplankton). *dan.mayoranoc.ac.uk

\section{KATHRYN B. COOK}

I am a Pelagic Biogeochemist at the National Oceanography Centre, investigating how the abundance and structure of marine zooplankton communities relate to the functioning of the ecosystems within which they reside. I studied marine biology at the University of Plymouth, and discovered my love of zooplankton whilst working as a zooplankton analyst at the Plymouth Marine Laboratory. After completing my Ph.D. in zooplankton ecology at University of Wales, Swansea, I worked at Marine Scotland Science (MSS) in Aberdeen as a plankton biologist.

\section{THOMAS R. ANDERSON}

I am a senior researcher at the National Oceanography Centre, Southampton. I make computer models to study the role of ocean plankton in the global carbon cycle and climate change. It is interesting work because, like plants and animals on land, there are many different types of plankton. Understanding this diversity, and how plankton live together in ecosystems, is the key to making successful model predictions. The models run on supercomputers that track the plankton as they circulate in the world ocean. When I am not working, I enjoy watching sport on TV, despite the groaning from my wife!

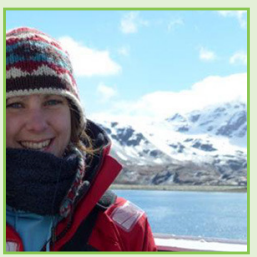

\section{ANNA BELCHER}

I am a marine scientist at the British Antarctic Survey in Cambridge, UK. I am really interested in how ocean biology is involved in the global carbon cycle and getting carbon dioxide out of the atmosphere. In particular, I study Antarctic krill, fish living in the dark ocean, as well as the importance of the food that copepods eat for their overwintering at depth. When I am not in the office or out at sea collecting data, I spend my time rock climbing, bike-packing, and enjoying the wild outdoors. 

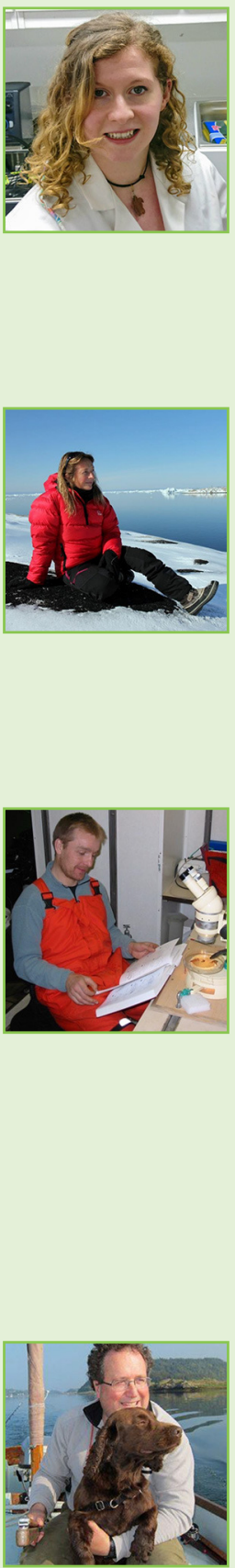

\section{HOLLY JENKINS}

I am a Ph.D. student at the National Oceanography Centre, UK. My background is marine biology, and I am interested in both the effects of climate change on marine animals and the way the animals affect climate change. My research looks at the diet of copepods to see what is needed for growth and reproduction. This is important to understand so we can anticipate how copepods will be affected by future climate change. I find copepods fascinating as they appear simple at first glance, but actually have complex daily movements, life cycles, and needs.

\section{PENNIE LINDEQUE}

I am a marine biologist at the Plymouth Marine Laboratory. My work focuses on zooplankton, small animals at the base of the marine food web. I develop and use molecular techniques to identify zooplankton, investigate what they eat and what eats them, and to look at their response to environmental stress and pollution. I am also interested in the source, distribution, and impact of microplastics and microdebris as marine contaminants on marine animals, including zooplankton.

\section{GERAINT A. TARLING}

I am a biological oceanographer at the British Antarctic survey. I work at both poles, surveying the range of animals inhabiting the sunlit and twilight oceanic zones. These organisms range from microscopic zooplankton to deep-dwelling fish, also encompassing gelatinous organisms, krill and pteropods (sea-butterflies). I am particularly interested in how they behave, most notably their daily migrations from ocean depths to the sea surface. I am also interested in how much carbon these communities move from the upper to the deeper parts of the ocean and how effective this process is in compensating for human emissions of $\mathrm{CO}_{2}$. When on long, polar voyages, I pass my spare time playing the accordion and spotting wildlife.

\section{DAVID POND}

I am based at the University of Stirling, studying how marine organisms utilize fats to succeed in life. I work at the interface between biochemistry and ecology, investigating how the biochemical composition of fat influences animal metabolism and health. My current work examines how marine copepods regulate their buoyancy and control key stages of their lives by changing the composition of fats within their bodies. This involves the use of an instrument that allows me to see how different fats change between being a solid and a liquid across the temperature and pressure gradients observed in our oceans. 